\title{
क क
}

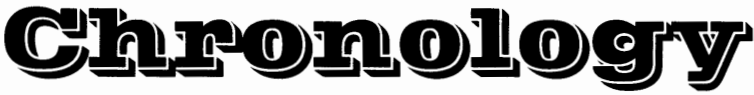

Summer 1826

February 12, I827

February 19, I827

February 28, 1827

March 8, I 827

March 20, I827

April 23, 1827

July 1827

February 27, 1828

March 3,1828

April 1828

May 23, I828

June IO, I 828

June $23, \mathrm{I} 828$

July $4, \mathrm{I} 828$

October 22, 1828

May 22, I829

July II-August 6, I 829
Serious railroad talks begin in Baltimore.

First meeting of Baltimore merchants to discuss railroad.

Second meeting results in decision to build railroad. Maryland legislature incorporates Baltimore and Ohio Railroad Company.

Virginia legislature approves B\&O Rr. charter.

City of Baltimore subscribes for 5,000 shares of B\&O Rr. stock.

B\&O Rr. Co. officially organized.

Surveys begin.

Pennsylvania legislature approves $\mathrm{B} \& \mathrm{O} \mathrm{Rr}$. charter. State of Maryland authorizes subscription for 5,000 shares of B\&O Rr. stock.

Engineers report on surveys.

Company adopts route, Baltimore to Potomac River. Chesapeake and Ohio Canal Company files suit to stop B\&O Rr. from acquiring more land along Potomac River.

B\&O Rr. files similar suit against C\&O Canal.

First stone laid for $B \& O \mathrm{Rr}$.

$\mathrm{B} \& \mathrm{O}$ engineers Jonathan Knight, William G.

McNeill, and George W. Whistler leave to study railroads in England.

$\mathrm{B} \& \mathrm{O}$ engineers return from England.

First court hearing, B\&O Rr. vs. C\&O Canal. 
October 6-I4, I829

October 1829

December 4, I829

December 21, I829

May 22, 1830

July 20, 1830

August 24, I830

August 28, 1830

September 20, 1830

June 28, I $83 \mathrm{I}$

June 29, I83I

October IO-25, I83I

December I, I83I

December 30, I83I

April I, I832

July I 832

September 1832

October 1832

March 9, I833

March 22, I833

June I 833

July I 833

June I 834

November I2, I 834

November I8-26, 1834

December I, I834
B\&O Rr.'s George Brown and Ross Winans attend locomotive trials held on Liverpool \& Manchester Rr. at Rainhill, England.

First track laid from Pratt Street to Carrollton Viaduct.

Patterson Viaduct officially opened.

Carrollton Viaduct officially opened.

B\&O Rr. officially opened to Ellicotts Mills.

Benjamin H. Latrobe, Jr., starts job on B\&O Rr.

Peter Cooper's locomotive makes first public appearance on B\&O Rr.

Oliver Viaduct officially opened. Peter Cooper's locomotive runs to Ellicotts Mills and back.

Peter Cooper's locomotive races horse, and loses.

B\&O Rr. conducts own version of Rainhill locomotive trials.

Irish laborers riot at Sykesville, Md.

Second court hearing, B\&O Rr. vs. C\&O Canal.

Frederick Branch officially opened.

C\&O Canal wins third and final court hearing, allowing it to proceed alone along Potomac River from Point of Rocks to Harpers Ferry.

B\&O Rr. completed to Point of Rocks, Md.

Surveys begin for Washington Branch.

Atlantic, first Grasshopper engine, put in service on $\mathrm{B} \& \mathrm{O} \mathrm{Rr}$.

City extension completed from Mt. Clare to tidewater at City Block.

Maryland legislature passes law allowing $\mathrm{B} \& \mathrm{O} \mathrm{Rr}$. to build Washington Branch.

Maryland legislature authorizes $\mathrm{B} \& \mathrm{O}$ Rr. to build rail line along Potomac River from Point of Rocks to Harpers Ferry, effecting compromise with $\mathrm{C} \& \mathrm{O}$ Canal.

President Andrew Jackson rides on B\&O Rr. from Relay to Baltimore.

Construction of Thomas Viaduct and Washington Branch begins.

Irish laborers riot on Washington Branch. John Reeder's locomotive American explodes. More Washington Branch riots by Irish laborers. B\&O Rr. main line from Baltimore to Harpers Ferry officially opened. 
December 2, I834

May-June I835

July 4, I 835

August 7-9, I835

August 25, 1835

September 27, I835

April-August I 836

April 26, 1836

June 4, I 836

June 30,1836

December I 836

December 27, 1836

April-October 1837

November 1837

December 1837

February I4, I838

March I 838

June 1838

June-August I 838

November I838-April I839

February-October 1839

June I, I839

August 1839

August 24, I839

November 3, I839
Grasshopper locomotive Arabian pulls scheduled train over inclined planes at Parrs Spring Ridge. Surveys conducted, Cumberland to Wheeling and Pittsburgh.

Thomas Viaduct completed.

Bank riots in Baltimore.

Washington Branch officially opened.

Engineer Phineas Davis killed in locomotive accident on Washington Branch.

Surveys conducted, Harpers Ferry to Brownsville, Pa.

City of Baltimore authorizes subscription for $\$ 3$ million in B\&O Rr. stock.

State of Maryland authorizes subscription for $\$ 3$ million in B\&O Rr. stock.

Philip E. Thomas resigns as B\&O Rr. president. Bridge over Potomac River to Harpers Ferry completed.

B\&O Rr. elects Louis McLane president.

Surveys conducted, Harpers Ferry to Pittsburgh and Wheeling.

Jonathan Knight and Benjamin H. Latrobe, Jr., make inspection tour of other railroads.

$\mathrm{B} \& \mathrm{O}$ Rr. signs first contract with federal government to carry U.S. mail.

B\&O Rr. decides to build main line from Harpers

Ferry to Cumberland through Virginia.

Surveys begin from Baltimore to Harpers Ferry to reconstruct Old Main Line and build new route over Parrs Spring Ridge avoiding inclined planes.

Surveys begin from Wheeling eastward.

Cumberland bituminous coal successfully tested in $\mathrm{B} \& \mathrm{O}$ locomotives.

Location surveys conducted from Harpers Ferry to Cumberland.

Surveys conducted, Wills Creek-Casselman River area of Pennsylvania above Cumberland.

Locomotive Isaac McKim pulls first train on new route over Parrs Spring Ridge.

Construction begins, Harpers Ferry to Cumberland. Louis McLane leaves for England to market \$3.2 million worth of State of Maryland bonds allocated to $\mathrm{B} \& \mathrm{O} \mathrm{Rr}$.

McLane, having deposited bonds with London's Baring Brothers \& Co., returns from England. 
February I 840

July $23-25, \mathrm{I} 840$

May 30, 1842

November 3, I842

August-October 1843

February I 844

May 24, I844

July $\mathrm{I} 6, \mathrm{I} 845$

October I, $\mathrm{I} 846$

March 6, I847

August 25, I847

April I848-January I849

June 1848

September 13,1848

October II, I 848

May 23, I849

July I 849

November 1849

November I4, I849

March I850

September 1850

October Io, 1850

December 1850

January I $85 \mathrm{I}$
B\&O Rr. issues scrip to finance construction, Harpers Ferry to Cumberland.

Baltimore shop workmen conduct first strike on $\mathrm{B} \& \mathrm{O} \mathrm{Rr}$.

B\&O Rr. officially opened to Hancock, Md.

B\&O Rr. officially opened to Cumberland, Md. Benjamin H. Latrobe, Jr., conducts surveys for a Virginia route, Cumberland to Parkersburg and Wheeling.

B\&O Rr. signs first contract for large-scale coal shipments with New York Coal and Iron Co., Mt. Savage, Md.

Samuel F. B. Morse sends first telegraph message from Washington to Baltimore along B\&O's Washington Branch right-of-way.

Louis McLane, appointed minister to England by President Polk to deal with Oregon question, sails for England. Samuel Jones, Jr., appointed B\&O Rr. president pro-tem.

McLane returns and is reelected $\mathrm{B} \& \mathrm{O}$ president. Virginia legislature passes law providing right-ofway for B\&O Rr. to Wheeling.

$\mathrm{B} \& \mathrm{O}$ stockholders approve Virginia act and route to Wheeling.

Location surveys conducted from Cumberland to Wheeling.

First Winans Camel engine introduced on $\mathrm{B} \& \mathrm{O} \mathrm{Rr}$. Louis McLane resigns as president of $\mathrm{B} \& \mathrm{O} \mathrm{Rr}$. Thomas Swann elected president, B\&O Rr. Ground broken near Swanton, Md., for construction of $\mathrm{B} \& \mathrm{O} \mathrm{Rr}$. from Cumberland to Wheeling. Locust Point Branch and coal piers in Baltimore completed.

Irish workmen riot at Kingwood Tunnel, Va.

$\mathrm{B} \& \mathrm{O}$ directors vote to put entire line from Cumberland to Wheeling under contract.

Laborers strike and riot at Kingwood Tunnel.

Arbitrators rule that B\&O Rr. must follow Grave Creek route to Wheeling.

Chesapeake and Ohio Canal officially opened to Cumberland.

Irish workmen riot near Cumberland.

B\&O Rr. sells remaining State of Maryland bonds 
February 14, I85I

July 22, I85I

November I85I

May 8, 1852

June 22,1852

Fall 1852

December 24, I852

January I3, I853

March 27, 1853

March 28, I853

April I, I853

June 7,1853

December 1853

November 1854

May I, I857

June-July I 857 held by Baring Brothers \& Co., to New York's Brown Brothers \& Co.

Virginia legislature charters Northwestern Virginia Railroad Company, which later becomes B\&O Rr.'s Parkersburg Branch.

B\&O Rr. excursion to Piedmont, Virginia.

Work force reaches peak: 4,870 men, 995 horses.

Kingwood Tunnel completed.

B\&O Rr. excursion to Fairmont, Virginia.

Washington, D.C., station completed.

Track closed at Roseby's Rock, 25 miles below

Wheeling.

$\mathrm{B} \& \mathrm{O}$ Rr. officially opened to Wheeling.

Eight people killed, several injured on Cheat River grade in worst accident in B\&O Rr.'s 25 -year history. Board Tree Tunnel completed.

Railroad officially open for business, Baltimore to Wheeling.

Iron bridge completed over Monongahela River at Fairmont.

Wheeling station completed.

B\&O Rr. opens through rail connections to Columbus and points west, via Central Ohio Rr.

Northwestern Virginia Railroad (Parkersburg

Branch) completed. B\&O Rr. gains access to Cincinnati and Saint Louis via Marietta \& Cincinnati and Ohio \& Mississippi Rr's.

B\&O Rr. excursion, Baltimore-Saint Louis, and return. 

THE GREAT ROAD

弥 
"The United States themselves are essentially the greatest poem."

- Walt Whitman

Preface to Leaves of Grass (I855) 